Бондарєва Т. Г., к.е.н., доцент, (Національний університет водного господарства та природокористування, м. Рівне), Немкович О. Б., к.е.н. (Відокремлений структурний підрозділ «Рівненський коледж Національного університету біоресурсів і природокористування України», м. Рівне, Україна)

\title{
ОСОБЛИВОСТІ ОБЛІКУ ВИТРАТ ОСНОВНОЇ ДІЯЛЬНОСТІ СІЛЬСЬКОГОСПОДАРСЬКИХ ПІДПРИЕМСТВ
}

У статті розкрито сутність поняття «основна діяльність» згідно діючих нормативно-правових актів. Запропоновано авторське визначення поняття «витрати основної діяльності сільськогосподарських підприємств» та зазначено їх склад. Окреслено статті витрат, які є специфічними для галузі сільського господарства. Висвітлено особливості обліку загальновиробничих витрат та особливості закриття рахунку 23 «Виробництво» у сільськогосподарських підприємстBax.

Ключові слова: облік витрат, основна діяльність, сільськогосподарська діяльність, витрати основної діяльності сільськогосподарських підприємств, сільськогосподарська продукція, біологічні активи.

Постановка проблеми в загальному вигляді. Успішний розвиток сільськогосподарських підприємств відіграє важливу роль у забезпеченні економічної та соціальної стабільності держави. В останні роки галузь сільського господарства стала основою української економіки. У 2018 р. рівень рентабельності операційної діяльності підприємств сільського, лісового та рибного господарства склав $17,9 \%$ проти $8,1 \%$ у цілому по економіці країни. Наразі галузь має реальний потенціал для зростання, що забезпечить можливість для України зберегти та примножити здобутки в аграрному секторі.

Враховуючи, що основною метою діяльності будь-якого сільськогосподарського підприємства $€$ отримання прибутку у процесі виробництва, переробки та реалізації продукції, надання послуг, важливого значення набувають питання обліку витрат його основної діяльності, оскільки їх величина безпосередньо впливає на фінансовий результат діяльності даних суб'єктів господарювання.

Аналіз останніх досліджень і публікацій. Теоретичні та методичні аспекти обліку витрат діяльності сільськогосподарських підприємств знайшли своє відображення у працях М.Я. Дем'яненка, 
Н.І. Дорош, В.М. Жука, Є.В. Калюги, Г.Г. Кірейцева, А.А. Кузьмінського, Н.М. Малюги, М.Г.Михайлова, О.М. Петрука, Н.Л. Правдюк, П.Т. Саблука, В.В. Сопко, І.Б. Садовської, Л.К. Сука, Н.М.Ткаченко, В.Г. Швеця, В.О. Шевчука та ін. Не зменшуючи значення важливих напрацювань вітчизняних науковців з даної проблематики, автори статті вбачають потребу у поглибленому дослідженні окремих аспектів даного питання, а саме - в частині обліку витрат основної діяльності сільськогосподарських підприємств.

Формулювання цілей статті. Метою статті $є$ виокремлення особливостей обліку витрат основної діяльності підприємств галузі сільського господарства для раціональної його організації.

Виклад основного матеріалу дослідження. Сучасний стан сільськогосподарських підприємств в країні залежить від ефективності їх господарської діяльності, яка включає виробничу, комерційну, фінансову діяльність, а також інші види діяльності. Крім того, на даному етапі розвитку економіки України важливе місце відводиться зовнішньоекономічній та інвестиційній діяльності виробників аграрної продукції. Кожне сільськогосподарське підприємство, виходячи 3 умов свого функціонування, самостійно визначає основні напрями господарської діяльності, здійснює їі планування і реалізацію.

Як відомо, основними галузями у сільському господарстві, які впливають на спеціалізацію суб'єктів аграрного господарювання, $€$ рослинництво і тваринництво. При цьому характерною особливістю сільськогосподарського виробництва $€$ здатність рослинних і тваринних організмів до природного відтворення.

Щоб зрозуміти, які витрати відносяться до основної діяльності сільськогосподарських підприємств, необхідно, перш за все, визначитися з поняттям «основна діяльність».

Варто зазначити, що даний термін не містить жоден нормативно-правовий акт, який безпосередньо регламентує сільськогосподарську діяльність. Натомість його можна зустріти в законодавчих документах, що регулюють діяльність суб'єктів господарювання інших галузей економіки, згідно з якими, основна діяльність - це:

- операції, пов'язані з виробництвом або реалізацією товарів, виконанням робіт, наданням послуг, що забезпечують створення основної частки доходу підприємства [1];

- операції, пов'язані з виробництвом або реалізацією продукції (товарів, робіт, послуг), що $є$ головною метою створення підприємства і забезпечують основну частку його доходу [2];

- операції з виробництва і реалізації продукції (робіт, послуг), що є предметом створення підприємства [3]; 
- операції, пов'язані з виробництвом або реалізацією продукції (товарів, робіт, послуг), які визначають загальнодержавне значення підприємства [4].

На нашу думку, для цілей бухгалтерського обліку варто спиратися на визначення основної діяльності, що міститься у НПСБО 1 «Загальні вимоги до фінансової звітності», відповідно до якого під основною діяльністю розуміють «операції, пов'язані з виробництвом або реалізацією продукції (товарів, робіт, послуг), що $є$ головною метою створення підприємства і забезпечують основну частку його доходу» [5].

Як бачимо, у даному визначенні, як і в більшості вищезазначених підходів, першорядним критерієм віднесення діяльності до основної є частка доходу від цієї діяльності в загальному обсязі отриманого доходу підприємства.

Зауважимо, що в економічній літературі основну діяльність часто асоціюють $з$ операційною діяльністю. Проте поняття «операційна діяльність» $€$ ширшим, оскільки воно включає в себе як основну діяльність, так і інші види діяльності, які не $є$ інвестиційною чи фінансовою діяльністю [5].

Варто також взяти до уваги визначення терміну «сільськогосподарська діяльність», яке містить П(С)БО 30 «Біологічні активи», згідно якого «сільськогосподарська діяльність - це процес управління біологічними перетвореннями з метою отримання сільськогосподарської продукції та/або додаткових біологічних активів [6]. Крім того, пунктом 17 зазначеного стандарту визначено, що витрати, пов'язані з біологічними перетвореннями біологічних активів, визнаються витратами основної діяльності.

Враховуючи вищевикладене, можна сформулювати власне визначення поняття витрат основної діяльності сільськогосподарських підприємств, як витрат, що безпосередньо пов'язані з процесом виробництва сільськогосподарської продукції та біологічних активів.

Застосовуючи поняття «витрати основної діяльності сільськогосподарських підприємств», необхідно окреслити, які саме витрати вони включають. У найбільш загальному вигляді - це:

- прямі матеріальні витрати;

- прямі витрати на оплату праці;

- інші прямі витрати;

- змінні загальновиробничі витрати;

- постійні розподілені загальновиробничі витрати.

Даний перелік витрат формує виробничу собівартість.

Зазначимо, що виробничі витрати сільськогосподарських підприємств формуються на двох рівнях: 
ництво»;

- у виробництві вони відображаються на рахунку 23 «Вироб-

- у виробничих підрозділах - на рахунку 91 «Загальновиробничі витрати».

Орієнтовний перелік статей витрат містять Методичні рекомендації з планування, обліку і калькулювання собівартості продукції (робіт, послуг) сільськогосподарських підприємств, затверджених наказом Міністерства аграрної політики України від 18.05.2001 р. № 132 (далі - Методичні рекомендації № 132) [7]. Специфічними статтями у цьому переліку є статті: «насіння та посадковий матеріал», «добрива», «засоби захисту рослин (тварин)», «корма», які можуть бути використані тільки сільськогосподарськими підприємствами.

Витрати на виробництво сільськогосподарської продукції (біологічних активів) у плануванні та обліку групуються за статтями, які підприємство визначає самостійно і затверджує наказом про облікову політику.

Проведені дослідження дають підстави стверджувати, що у своїй практичній діяльності сільськогосподарські підприємства можуть здійснювати розподіл загальновиробничих витрат у відповідності до Методичних рекомендації № 132 або ж згідно П(С)БО 16 «Витрати».

Так, згідно Методичних рекомендацій № 132, сільськогосподарські підприємства всі загальновиробничі витрати умовно вважають змінними та розподіляють їх між основними галузями і об'єктами витрат пропорційно до суми прямих витрат (крім вартості насіння, кормів та сировини). Виключенням є сума єдиного податку для платників четвертої групи, яку у кінці звітного періоду (року) розподіляють між об'єктами обліку витрат продукції рослинництва пропорційно до площ сільськогосподарських угідь (ріллі, сіножатей, пасовищ, багаторічних насаджень та перелогів), зайнятих відповідними культурами, а в рибницьких, рибальських та риболовецьких господарствах - відповідно до площ земель водного фонду, які використовуються такими господарствами для розведення, вирощування та вилову риби у внутрішніх водоймах (озерах, ставках та водосховищах).

Своєю чергою, П(С)БО 16 «Витрати» пропонує поділ загальновиробничих витрат на постійні і змінні та базу їх розподілу (години праці, заробітна плата, обсяг діяльності, прямі витрати тощо) [8].

На нашу думку, доцільно здійснювати розподіл загальновиробничих витрат у відповідності до Методичних рекомендацій № 132, що $€$ більш оптимальним для сільськогосподарських підприємств, враховуючи специфіку їх діяльності.

Коротко зупинимося на порядку закриття рахунку 23 «Вироб- 
ництво» у сільськогосподарських підприємствах, який також має свою специфіку. Згідно з П(С)БО 30 «Біологічні активи», сільськогосподарські підприємства при первісному визнанні додаткових біологічних активів і сільськогосподарської продукції оцінюють їх за одним із двох варіантів:

1) за справедливою вартістю, зменшеною на очікувані витрати на місці продажу;

2) за виробничою собівартістю згідно з П(С)БО 16 «Витрати».

Спосіб оцінки, який буде обраний підприємством, має бути зафіксований у наказі про облікову політику підприємства. Виходячи 3 того, що існують різні методи оцінки, порядок закриття рахунку 23 «Виробництво» буде відрізнятися (таблиця).

Таблиця

Особливості закриття рахунку 23 «Виробництво»в залежності від обраного методу оцінки сільськогосподарської продукції

(біологічного активу)

\begin{tabular}{|c|c|}
\hline $\begin{array}{c}\text { Оцінка за справедливою } \\
\text { вартістю }\end{array}$ & Оцінка за виробничою собівартістю \\
\hline $\begin{array}{l}\text { Знаходиться різниця між справед- } \\
\text { ливою вартістю оприбуткованої про- } \\
\text { дукції (біологічного активу) та сумою } \\
\text { понесених витрат, пов'язаних з її бі- } \\
\text { ологічним перетворенням (різниця } \\
\text { між дебетом і кредитом рахунка 23) } \\
\text { Результат оформляється такими за- } \\
\text { писами: } \\
\text { - Дт } 23 \text { - Кт } 710 \text { - якщо справе- } \\
\text { длива вартість сільгосппроду- } \\
\text { кції перевищує суму понесе- } \\
\text { них витрат; } \\
\text { - Дт 940 - Кт } 23 \text { - якщо справе- } \\
\text { длива вартість сільгосппроду- } \\
\text { кції менше суми понесених ви- } \\
\text { трат }\end{array}$ & $\begin{array}{l}\text { 1. Оприбутковується створена продук- } \\
\text { ція (біологічний актив) за плановою со- } \\
\text { бівартістю: } \\
\text { (Дт 27, } 21 \text { - Кт 23). } \\
\text { 2. Закриття рахунку: } \\
\checkmark \text { методом «червоне сторно» (планова } \\
\text { собівартість перевищує фактичну) } \\
\text { - } \quad \text { продукція на кінець року не реа- } \\
\quad \text { лізована: Дт } 27,21 \text { - Кт } 23 \\
\text { - продукція на кінець року реалі- } \\
\quad \text { зована: Дт } 901-\text { Кт } 27,21 \\
\text { методом додаткових проведень } \\
\text { (планова собівартість менше фактичноі) } \\
\text { - продукція на кінець року не реа- } \\
\quad \text { лізована: Дт } 27,21 \text { - Кт } 23 \\
\text { - продукція на кінець року реалі- } \\
\quad \text { зована: Дт } 901 \text { - Кт } 27,21\end{array}$ \\
\hline
\end{tabular}

У разі, якщо оцінювати вироблену продукцію (біологічні активи) за справедливою вартістю, то така оцінка ніяк не пов'язана з фактичними витратами, понесеними на виробництво продукції (біологічного активу). Тому, щоб коректно закрити рахунок 23, на якому були накопичені витрати, потрібно визнати або доходи, або витрати від первісного визнання сільськогосподарської продукції чи біологічного активу.

Підприємство, яке здійснює оцінку за фактичною собівартістю, 
може визначити виробничу собівартість тільки в кінці року (після розподілу загальновиробничих витрат). Впродовж року продукція (біологічний актив) обліковується за плановою собівартістю. Тільки наприкінці року, коли будуть повністю сформовані витрати на вирощування такої продукції, а також розподілені загальновиробничі витрати, можна буде визначити різницю між плановою собівартістю і фактичними витратами та закрити рахунок 23 (див. таблицю). Різниця між фактичною та плановою собівартістю продукції відноситься пропорційно на ті рахунки бухгалтерського обліку, на які ця продукція була списана впродовж року, а також на залишок продукції на кінець року.

Висновки. Таким чином, витрати основної діяльності сільськогосподарських підприємств - це витрати, що безпосередньо пов'язані з процесом виробництва сільськогосподарської продукції та біологічних активів. Вони включають: прямі матеріальні витрати; прямі витрати на оплату праці; інші прямі витрати; змінні та постійні розподілені загальновиробничі витрати. Специфічними для сільськогосподарських підприємств статтями витрат є: «насіння та посадковий матеріал», «добрива», «засоби захисту рослин (тварин)», «корма». Характерним в обліку витрат основної діяльності сільськогосподарських підприємств є розподіл загальновиробничих витрат, який можна здійснювати згідно Методичних рекомендацій № 132 або у відповідності до П(С)БО 16. Ще однією важливою особливістю $є$ закриття рахунку 23 «Виробництво» в залежності від обраної підприємством методики оцінки (за справедливою вартістю чи за виробничою собівартістю) сільськогосподарської продукції (біологічного активу). Зазначені аспекти важливо враховувати у процесі організації обліку витрат, адже саме цей елемент формує собівартість виготовленої продукції, яка у значній мірі впливає на величину отриманого прибутку виробників сільськогосподарської продукції.

1. Про затвердження Порядку формування тарифів на теплову енергію, її виробництво, транспортування та постачання, послуги з централізованого опалення і постачання гарячої води : Постанова Національної комісії, що здійснює державне регулювання у сферах енергетики та комунальних послуг від 24.03.2016 № 377. Дата оновлення: 20.04.2019. URL: https://zakon.rada.gov.ua (дата звернення: 04.03.19). 2. Методичні рекомендації з відображення покупної електроенергії підприємствами, які існують в ДП «Енергоринок», з метою подальшого продажу споживачам електричної енергії : протокол засідання методологічної ради від 08.04.2003 № 2. Дата оновлення: 08.04.2003. URL: https://zakon.rada.gov.ua (дата звернення: 04.03.19). 3. Міжгалузеві норми часу та чисельності працівників на роботи, 
що виконуються економістами з фінансової роботи : наказ Міністерства праці та соціальної політики України 07.12.2006 № 459. Дата оновлення: 07.12.2006. URL: https://zakon.rada.gov.ua (дата звернення: 04.03.19). 4. Про порядок віднесення майна до такого, що включається до складу цілісного майнового комплексу державного підприємства : наказ Фонду державного майна України від 29.12.2010 № 1954. Дата оновлення: 03.08.2018. URL: https://zakon.rada.gov.ua (дата звернення: 04.03.19). 5. Національне положення (стандарт) бухгалтерського обліку 1 «Загальні вимоги до фінансової звітності» : наказ Міністерства фінансів України від 07.02.2013 № 73. Дата оновлення: 03.08.2018. URL: https://zakon.rada.gov.ua (дата звернення: 04.03.19). 6. Положення (стандарт) бухгалтерського обліку 30 «Біологічні активи»: наказ Міністерства фінансів України від 18.11.2005 № 790. Дата оновлення: 05.01.2018. URL: https://zakon.rada.gov.ua (дата звернення: 04.03.19). 7. Методичні рекомендації з планування, обліку і калькулювання собівартості продукції (робіт, послуг) сільськогосподарських підприємств : наказ Міністерства аграрної політики України від 18.05.2001 № 132. Дата оновлення: 31.10.2005. URL: https://zakon.rada.gov.ua (дата звернення: 04.03.19). 8. Положення (стандарт) бухгалтерського обліку 16 «Витрати»: Наказ Міністерства фінансів України від 31.12.1999 № 318. Дата оновлення: 09.08.2013. URL: https://zakon.rada.gov.ua (дата звернення: 04.03.19).

\section{REFERENCES:}

1. Pro zatverdzhennia Poriadku formuvannia taryfiv na teplovu enerhiiu, yii vyrobnytstvo, transportuvannia ta postachannia, posluhy z tsentralizovanoho opalennia i postachannia hariachoi vody: Postanova Natsionalnoi komisii, shcho zdiisniuie derzhavne rehuliuvannia u sferakh enerhetyky ta komunalnykh po-sluh vid 24.03.2016 № 377. Data onovlennia: 20.04.2019. URL: https://zakon.rada.gov.ua (data zvernennia: 04.03.19). 2. Metodychni rekomendatsii z vidobrazhennia pokupnoi elektroenerhii pidpryiemstvamy, yaki isnuiut v DP «Enerhorynok», z metoiu podalshoho prodazhu spozhyvacham elektrychnoi enerhii : protokol zasidannia metodolohichnoi rady vid 08.04.2003 № 2. Data onovlennia: 08.04.2003. URL: https://zakon.rada.gov.ua (data zvernennia: 04.03.19). 3. Mizhhaluzevi normy chasu ta chyselnosti pratsivnykiv na roboty, shcho vykonuiutsia ekonomistamy z finansovoi roboty : nakaz Ministerstva pratsi ta sotsialnoi polityky Ukrainy 07.12.2006 № 459. Data onovlennia: 07.12.2006. URL: https://zakon.rada.gov.ua (data zvernennia: 04.03.19). 4. Pro poriadok vidnesennia maina do takoho, shcho vkliuchaietsia do skladu tsilisnoho mainovoho kompleksu derzhavnoho pidpryiemstva : nakaz Fondu derzhavnoho maina Ukrainy vid 29.12.2010 № 1954. Data onovlennia: 03.08.2018. URL: https://zakon.rada.gov.ua (data zvernennia: 04.03.19). 5. Natsionalne polozhennia (standart) bukhhalterskoho obliku 1 «Zahalni vymohy do finansovoi zvitnosti»: nakaz Ministerstva finansiv Ukrainy vid 07.02.2013 № 73. Data onovlennia: 03.08.2018. URL: https://zakon.rada.gov.ua (data 
zvernennia: 04.03.19). 6. Polozhennia (stan-dart) bukhhalterskoho obliku 30 «Biolohichni aktyvy»: nakaz Ministerstva finansiv Ukrainy vid 18.11.2005 № 790. Data onovlennia: 05.01.2018. URL: https://zakon.rada.gov.ua (data zvernennia: 04.03.19). 7. Metodychni rekomendatsii z planuvannia, obliku i kalkuliuvannia sobivartosti produktsii (robit, posluh) silskohospodarskykh pidpryiemstv : nakaz Ministerstva ahrarnoi polityky Ukrainy vid 18.05.2001 № 132. Data onovlennia: 31.10.2005. URL: https://zakon.rada.gov.ua (data zvernennia: 04.03.19). 8. Polozhennia (standart) bukhhalterskoho obliku 16 «Vytraty»: Nakaz Ministerstva finansiv Ukrainy vid 31.12.1999 № 318. Data onovlennia: 09.08.2013. URL: https://zakon.rada.gov.ua (data zvernennia: 04.03.19).

Bondarieva T. H., Candidate of Economics (Ph.D.), Associate Professor (National University of Water and Environmental Engineering, Rivne), Nemkovych O. B., Candidate of Economics (Ph.D.), (Rivne College of National University of Life and Environmental Sciences of Ukraine, Rivne)

\section{ACCOUNTING EXPENSES PECULIARITIES OF THE AGRICULTURAL ENTERPRISES' MAIN ACTIVITY}

The article reveals the essence of the concept "main activity" in accordance with the current normative legal acts. It is determined that the primary criterion for assigning activities to the main is the share of income received from this activity in the total amount of income received by the enterprise.

The actual definition of the concept "costs of agricultural enterprises' main activity" is formulated as expenses directly related to the process of agricultural production and biological assets.

It is determined that agricultural enterprises' production costs are formed on two levels: in production, they are reflected in the account 23 "Production"; in the production departments - in the account 91 "Total production costs".

In the article, from the indicative list of expenses, specific articles are marked: "seeds and planting material", "fertilizers", "means of plants (animals) protection", "fodder", which can be used only by agricultural enterprises.

The peculiarities of accounting of the total production costs, namely, their distribution, which agricultural enterprises can carry out in accordance with the Methodological recommendations on planning, accounting and calculation of the products cost (operations, services) 
of agricultural enterprises or the Regulation (standard) of accounting 16 "Expenses" are highlighted.

The article outlines the procedure of closing the account 23 "Production" in the agricultural enterprises, depending on the option of chosen evaluation of additional biological assets and agricultural products, namely: by fair value, reduced by the expected expenses on the sales site; by the production cost according to the Regulation (standard) of accounting 16 "Expenses".

It is important to consider these aspects in the process of organizing accounting costs, because this very element forms the cost of manufactured products, which greatly affects the amount of profits made by agricultural manufacturers.

Keywords: accounting expenses, main activity, agricultural activity, expenses of the agricultural enterprises' main activity, agricultural products, biological assets

Бондарева Т. Г., к.э.н., доцент (Национальный университет водного хозяйства и природопользования, г. Ровно), Немкович О. Б., к.э.н. (Обособленное структурное подразделение «Ровенский колледж Национального университета биоресурсов и природопользования Украины», г. Ровно)

\section{ОСОБЕННОСТИ УЧЕТА РАСХОДОВ ОСНОВНОЙ ДЕЯТЕЛЬНОСТИ СЕЛЬСКОХОЗЯЙСТВЕННЫХ ПРЕДПРИЯТИЙ}

В статье раскрыта сущность понятия «основная деятельность» согласно действующих нормативно-правовых актов. Предложено авторское определение понятия «затраты основной деятельности сельскохозяйственных предприятий» и указано их состав. Определены статьи расходов, которые являются специфическими для отрасли сельского хозяйства. Показаны особенности учета общепроизводственных расходов и особенности закрытия счета 23 «Производство» в сельскохозяйственных предприятиях. Ключевые слова: учет расходов, основная деятельность, сельскохозяйственная деятельность, расходы основной деятельности сельскохозяйственных предприятий, сельскохозяйственная продукция, биологические активы. 